\title{
Determinants of sovereign debt yield spreads under EMU: Pairwise approach
}

Citation for published version (APA):

Fazlioglu, S. (2013). Determinants of sovereign debt yield spreads under EMU: Pairwise approach. Maastricht University, Graduate School of Business and Economics. GSBE Research Memoranda No. 007 https://doi.org/10.26481/umagsb.2013007

Document status and date:

Published: 01/01/2013

DOI:

10.26481/umagsb.2013007

Document Version:

Publisher's PDF, also known as Version of record

\section{Please check the document version of this publication:}

- A submitted manuscript is the version of the article upon submission and before peer-review. There can be important differences between the submitted version and the official published version of record.

People interested in the research are advised to contact the author for the final version of the publication, or visit the DOI to the publisher's website.

- The final author version and the galley proof are versions of the publication after peer review.

- The final published version features the final layout of the paper including the volume, issue and page numbers.

Link to publication

\footnotetext{
General rights rights.

- You may freely distribute the URL identifying the publication in the public portal. please follow below link for the End User Agreement:

www.umlib.nl/taverne-license

Take down policy

If you believe that this document breaches copyright please contact us at:

repository@maastrichtuniversity.nl

providing details and we will investigate your claim.
}

Copyright and moral rights for the publications made accessible in the public portal are retained by the authors and/or other copyright owners and it is a condition of accessing publications that users recognise and abide by the legal requirements associated with these

- Users may download and print one copy of any publication from the public portal for the purpose of private study or research.

- You may not further distribute the material or use it for any profit-making activity or commercial gain

If the publication is distributed under the terms of Article $25 \mathrm{fa}$ of the Dutch Copyright Act, indicated by the "Taverne" license above, 


\section{Maastricht University}

Seher Fazlioglu

Determinants of sovereign debt yield spreads under EMU: Pairwise approach

$\mathrm{RM} / 13 / 007$

\section{GSBE}

Maastricht University School of Business and Economics

Graduate School of Business and Economics

P.O Box 616

NL- 6200 MD Maastricht

The Netherlands 


\title{
Determinants of sovereign debt yield spreads under EMU: Pairwise approach
}

\author{
Seher Fazlıoğlu \\ Maastricht University, Department of Economics, PO Box 616, MD 6200, Maastricht, The Netherlands ; Email: \\ s.fazlioglu@maastrichtuniversity.nl
}

\begin{abstract}
This study aims at providing an empirical analysis of long-term determinants of sovereign debt yield spreads under European EMU (Economic and Monetary Union) through pairwise approach within panel framework. Panel gravity models are increasingly used in the cross-market correlation literature while to our knowledge, this is the first empirical study employing the method in the bond market literature. Accordingly, sovereign yield spreads are positively related to differential government debt ratio while negatively related to relative economic growth performance, differential liquidity of the individual debt markets as well as governance quality. Moreover, non-linear dynamic panel estimates indicate that markets seem to ignore fundamentals after the emerge of EMU while the very same risk factors are revalued by the markets after the 2008/2009 financial crisis. Furthermore, markets price fiscal indebtedness more among the EMU members than among the non-EMU members. Finally, the results of the dynamic panel model are robust to different estimation techniques such as GMM as well as sample selection.
\end{abstract}

Keywords: Sovereign debt rate spread, Panel data, Pairwise approach, Default risks in EU countries

JEL: H63, E43, C23

\footnotetext{
${ }^{1}$ The author thanks Prof.Bertrand Candelon for discussions and advices.
} 


\section{Introduction}

Following the elimination of currency risk in January 1999 with the establishment of European EMU (Economic and Monetary Union), European government bond markets show an increasing degree of integration in the union and considered as a single market. Most of the studies conducted to analyze this period argue that the market participants price convergence expectations among the members while the global risk factors are main drivers of the yield spreads among the members. Thus, fundamental economic developments such as differences in fiscal strength, debt ratios, relative economic growth performance were ignored by the bond markets. Nevertheless, market perception of member countries' default risk have essentially been readjusting since the 2008/2009 financial crisis. In other words, the variety in economic fundamentals within the Euro-zone have been revalued by the markets and have reflected the borrowing cost across the members.

What drives the sovereign debt yield spreads in the Eurozone becomes more crucial for policy implementation to preserve the existence of single currency. However, neither theory nor empirical evidence provides a definitive guideline. Economic theory suggests that worsening fiscal positions push interest rates up, causing to decrease investment and growth in the long-run (Elmendorf and Mankiw [18]) while possible offset by increase in private savings or in international capital flows might reverse the effects (Faini [19], Linnemann and Schabert [30]). From macro perspective, textbook IS-LM accounts emphasize the budget deficit as the determinants of interest rates whereas micro-founded general equilibrium models tend to put the stock of debt at the center. While many studies formalize a model of sovereign borrowing within the maximization problem of an open economy, the others draw the reduced-form equation from a simple mean-variance portfolio model through introducing default, liquidity as well as country specific risks. Nevertheless, given the theory does not settle the matter, the focus is on empirical evidence.

In this respect, the determinants of sovereign interest rates/yields have been the subject of extensive, yet inconclusive empirical literature. Early works are based on time series evidence from single countries, mainly the US bond markets since the economy has the largest and most 
mature bond market in the world while the EMU provides cross-country evidence to the research and stimulate a considerable amount of empirical literature on the subject. The studies aim to identify the affects of a set of factors such as economic indicators, liquidity indicators, global risk factors as well as governance indicators. The papers broadly find some evidence for the explanatory power of such factors whereas the results and conclusions vary drastically across studies. The analyses are different in terms of methodologies, explanatory variables, sample countries as well as sample periods and even in terms of the dependent variable.

This study aims to provide an empirical analysis of long-term determinants of sovereign debt yield spreads of 11 EMU member states (Austria, Belgium, Finland, France, Germany, Greece, Ireland, Italy, Netherlands, Portugal, Spain) as well as 3 non-EMU members (Denmark, Sweden, United Kingdom) using annual data covering period from 1996 to 2011. To correct foreign exchange rate risk component for pre-EMU period as well as for non-EMU members, default risk is measured by the spread of 10-year benchmark government bond yields over the corresponding swap yield of the same 10-year maturity denominated in the same currency ${ }^{2}$. So, dependent variable is adjusted spread as the difference between yield differential and swap rate differential. Moreover, broadly based on the literature, we categorize common macroeconomic factors likely to affect sovereign debt yield spreads into four: economic indicators, liquidity indicators, global risk factors as well as governance indicators. In this respect, the paper try to shade some lights on the question of which risk factor matters most in the long-run?

Furthermore, the main contributions of this study to existing literature are to adopt the pairwise approach as well as non-linear dynamic panel analysis. Conventional way to work in the bond market literature is to adopt the base country approach and calculate the spread compared with benchmark country. In this study, we conduct the dependent variable as N(N-1)/2 longterm interest rate differentials between pairs of $\mathrm{N}$ countries and analyze in a dynamic panel

\footnotetext{
${ }^{2}$ The literature broadly indicates three potential measures to correct the currency risk: 1) long-term bonds issued by the same supra-national organization such as World Bank, 2) long-term bonds issued by the private sector and 3) the fixed interest rates on swap contracts. Favero, Giavazzi, and Spaventa [20] explicitly discuss measures of the component of yield differentials excluding exchange rate risks.
} 
framework in line with Beine and Candelon [9]. Within this framework, explanatory variables are calculated for each country pair to investigate which factors impact the yield spreads. The conventional procedure is sensitive to the choice of the base country and undermine the information in all the other cross-country comparisons. For example, it could be that the interest rate differentials between a pair of counties, such as Italy and Greece, are more driven by countries' fiscal discipline and competitiveness of the economies while their spreads computed separately against Germany is affected by global financing conditions. Note that pairwise approach is adopted from the gravity model which is widely used in the empirical trade literature. Starting from Brahmasrene [14] which implements the model to explain stock market correlations, the model offers a tool to the financial literature. Despite fact that it has been used in explaining the development of cross-market correlations, to our knowledge this is the first empirical study employing pairwise approach in the bond market literature.

Secondly, non-linear dynamic panel analysis explores potential structural breaks in the coefficients in terms of time and country. The explanatory variables are interacted with EMU dummy and Crisis dummy to test for structural breaks in the coefficients after the start of EMU as well as the $2008 / 2009$ crisis. On the other hand, due to the bilateral nature of the data, cross section dependence is likely to be present. We work with Feasible Generalized Least Square (FGLS) to treat cross sectional dependence. Furthermore, there is identification problem for fiscal variables since they are cyclically responsive to the interest rates. Due to this endogeneity, there is no consensus on what fiscal variable should be employed as indication of fiscal outlook. ${ }^{3}$. The literature also suggests either to work with the projected fiscal variables to anticipate the forward looking behavior of the markets or work with GMM.

The results of the study suggest that for the yield spreads, significant explanatory variables are differential government debt ratio, economic growth rates, liquidity and governance quality. Moreover, non-linear dynamic panel estimates indicate that markets seem to ignore fundamentals after the emerge of EMU while the very same risk factors are revalued by the markets

\footnotetext{
${ }^{3}$ In this respect, flow fiscal variables such as public consumption, deficit, primary deficit (Laubach [27]) are employed while stock fiscal variables such as public debt ratios are also widely used (Schuknecht, von Hagen, and Wolswijk [36].
} 
after the 2008/2009 financial crisis. Furthermore, it is investigated whether the relationship between independent variables and bond yield spreads changes due to both parties being members of EMU. Accordingly, markets price fiscal indebtedness more among the EMU members than among the non-EMU members. Finally, the results of the dynamic panel model are robust to different estimation techniques such as GMM as well as sample selection. Respectively, sovereign yield spreads are positively related to differential government debt ratio while negatively related to relative economic growth performance, differential liquidity of individual debt markets as well as governance quality.

The remainder of the paper is organized as follows: Section 2 presents literature review while a number of potential determinants are discussed and identified in Section 3. Section 4 defines econometric framework whereas section 5 discusses the data set used and presents the estimations and the results and section 6 finally states concluding remarks.

\section{Literature review}

The research question of what drives the sovereign debt yield spreads has been studied by a large body of empirical literature given that theory hardly settles the matter. The papers broadly find some evidence for the explanatory power of risk factors whereas the results and conclusions vary drastically across studies. The analyses are different in terms of methodologies, explanatory variables, sample countries as well as sample periods and even in terms of the dependent variable.

A first line of research aims to trace out the effects of fiscal imbalance especially budget deficits on sovereign borrowing costs. Note that IS-LM accounts emphasize the flows fiscal variables at center while micro-founded general equilibrium models focus on the level of debt. Moreover, due to the endogenity of fiscal positions to the business cycle, views differ on what fiscal variable such as actual or forward projected public consumption or deficit or debt should be employed to proxy fiscal positions. Accordingly, Gale and Orszag [21] conclude that expected deficits affect long-term interest rates positively for the US while Laubach [27] and Thomas and Wu [38] also confirm this result. Furthermore, Canzoneri, Cumby, and Diba [15] 
show that expected deficits affect the spread between long and short-term interest rates in the US. Heppke-Falk and HÃijfner [26] study whether expected budget deficits have an impact on interest rate swap spreads in France, Germany and Italy and find positive impact on those yield spreads. Gruber and Kamin [24] find a robust and significant effect of fiscal performance which is measured by projected series on long-term bond yields by analyzing 19 OECD countries over the period of 1988-2007 in panel setup. Finally, Ardagna, Caselli, and Lane [2] use a panel of 16 OECD countries covering the period of 1960-2002 through employing static as well as dynamic econometric models. The study claims a positive effect of primary deficits as well as the accumulated public debt on long-term interest rates. The paper also points out the non-linear effect of government debt on interest rates: It becomes stronger as a country debt grows. Note that in the robustness check, the spread of 10-year government bond interest rate over the swap interest rate is used as a dependent variable and the coefficients of primary deficit and government debt ratios become statistically insignificant. Since, this measurement is considered as a default risk measurement in the literature, it is argued that the impact of the fiscal policy on interest rates is not likely to be via default risk directly, but could be through expected inflation or the demand for loanable funds which have potentials to affect the swap markets,too.

Second line of research focuses on the stock of sovereign debt as fiscal performance through analyzing the interest rate spreads between government bonds and suitable benchmark assets. In this respect, there are many papers investigating subnational government bonds markets ${ }^{4}$ and find the government debt over GDP to be significant on yield spreads whereas it lacks to address how the sovereign risk of national government bonds are priced. In this respect, Balassone, Franco, and Giordano [6] show that yield spreads of EU countries against Germany between 1980 and 2003 depend positively on the change in the government debt-to-GDP ratio.

\footnotetext{
${ }^{4}$ Bayoumi, Goldstein, and Woglom [8] and Poterba and Rueben [35] study the yield differentials of 39 US states relative to New Jersey and find the positive effects of the debt level on the differentials. Lemmen [28] employs yield of bonds issued by subnational governments in Austria, Canada and Germany and find the yield spreads over central government bond yields depend positively on the ratio of government debt-to-GDP. Booth, Georgopoulos, and Hejazi [13] show that bond yields of Canadian provinces over the federal government respond positively to measures of subnational indebtedness.
} 
However, main drawback of this approach is that it is hardly decompose credit as well as exchange rate risks since issues are denominated in local currencies. Gómez-Puig [23],[29] and Codogno, Favero, and Missale [16] employs the adjusted spreads of the yields on bonds, where the yields in local-currency-denominated are subtracted from the appropriate interest rate swap rates to eliminate the exchange rate risks and find that the differentials depend positively on the level of public debt. The literature indicates other measurements to correct currency risk: Alesina, Broeck, Prati, Tabellini, Obstfeld, and Rebelo [1] focus on 12 OECD countries and show that the differential between public and private bond yields is positively related to the level of public debt while Looning [31] study the yields of a very small sample of DM issues of $11 \mathrm{EU}$ governments compared with German government bonds in the mid-1990s and indicates a positive, however not always significant impact of government debt and deficits.

The introduction of EMU in 1999 stimulated a considerable amount of empirical literature on the determinants of Euro-zone government bond yield spreads and the literature has substantially expanded following the global financial crisis in 2008. While the earlier literature indicates some similarities on the determinants of the sovereign yield spreads, there is no consensus on the key drivers. Bernoth, von Hagen, and Schuknecht [10] study the period of 1993-2005 for 14 EU countries and find debt-to-GDP, deficit-to-GDP, debt service on revenues, US corporate bond spreads, a EMU dummy, the short-term US rate and liquidity of the issue as statistically significant. Schuknecht, von Hagen, and Wolswijk [36] detect debt-to-GDP, fiscal balance to GDP, US corporate bond spreads, region dummies, liquidity and the maturity of the issue and the short-term US rate as vital determinants of sovereign yield spreads. von Hagen, Schuknecht, and Wolswijk [39] confirm these results, but also argue that crises dummies to be significant. Codogno, Favero, and Missale [16] point out that only debt-to-GDP, US swap spread and US corporate bond spreads significant. On the other hand, Manganelli and Wolswijk [32] only note that ratings and short-term interest rates as crucial yield spread drivers.Given the high uncertainty about the "true" empirical model, Dominik [17] suggests to work with Bayesian Model Averaging (BMA) approach to account explicitly for high uncertainty by considering the entire model space. By considering 10 EMU member countries from the period of 1999-2009, it 
is stated that budget balance to GDP, terms of trade, trade balance and countries' openness are main drivers of sovereign yield spreads in the Eurozone.

Finally, there is growing literature to address the question of how the recent economic and financial crisis have affected bond pricing in the Eurozone. This literature employs the theory that underlines impacts of macroeconomic fundamentals based on cash flow determinants, risk determinants and the interaction of the two. Accordingly, Haugh, Ollivaud, and Turner [25] analyze the yield spreads between 10 EU countries and Germany covering December 2005June 2009. They confirm that future deficits and the debt service ratio have important role in explaining bond yield spreads in the Euro-zone. They further argue that the importance of each fiscal variables increases with the interaction of lower global risk appetite. Barrios, Iversen, Lewandowska, and Setzer [7] study the panel of 7 EMU countries covering the period of 2003q1-2009q2, find that euro area spreads are strongly influenced by domestic factors like liquidity and credit risk that this effect intensify during the stressed economic environment. Sgherri and Zoli [37] estimate a panel model covering monthly government bond yield spreads between 10 EU countries and Germany over the period of January 2003-March 2009. They argue that the significant deterioration in fiscal position after the financial crisis have been priced severely by the markets. Oliveira, Curto, and Nunes [34] study the database of Eurodenominated government bonds for 8 EMU countries covering the period of 2000q1 to 2010q4. It is argued that macroeconomic country specific variables become important after the financial crisis while the market-related factors mainly determinate the yield spreads during the precrisis period. Finally, Bernoth, von Hagen, and Schuknecht [11] analyze the foreign-currency denominated long-term bond yields for 14 EU countries including 3 non-EMU members with the period of 1993-2009. It is stated that the yield spreads are sensitive to the measures of the government indebtedness both before and after the start of EMU. Furthermore, after the start of EMU, markets seem to pay less attention on government levels than before while the deficits and debt service ratios are continued to be monitored. 


\section{Potential underlying determinants}

The sovereign yield spreads are determined by a large number of factors. For instance, the rating agencies such as Moody's and S\&P spell out the list numerous economic, political and social factors that underline sovereign credit ratings. Based on the earlier studies, the variables that are found to be significant in other papers are identified as potential drivers of the sovereign debt spreads. The variables can be broadly classified into economic indicators, liquidity, global risk as well as governance indicators.

Economic indicators: These variables relate to the country's long-term ability to pay its debt such as its fiscal outlook, state of the economy, external sector indicators.

- Budget balance as \% of GDP: It is a flow fiscal variable. A large fiscal deficit indicates that the government lacks the ability to correct taxes to cover its current expenses, indication of weak tax system or weak state of the economy. Thus, higher negative budget balance is supposed to lead to higher market perception of default risk, higher yield spreads.

- Total government debt as \% of GDP: It is stock fiscal variable. The higher the debt burden, the larger the transfer effort the country need to make over time to service its obligations. Thus, higher indebtedness increases the default risk, therefore increases yield spreads. However, note that this indicator does not spell out on the debt service burden on a country, which also affected by the maturity structure as well as the yield of the debt.

- Real GDP growth: A high economic growth rate normally generates a better fiscal position and this indicates that country's debt burden will be easier over time. Basic theorical framework such as Domar $(1944,1950)$ points out the relationship between the growth rate of GDP and the growth rate of debt. From a theorical point of view, the burden of the debt, even if the debt is constantly growing, is not a problem as long as the debt grows at slower rate than the real GDP.

- Inflation: Inflation may have an influence on default risk in several ways despite the fact that all EMU member states face the same monetary policy. Higher inflation rates, i.e. in- 
creasing price differentials, for example, lead to a loss in competitiveness, which increases the default risk. In the case of EMU member states the influence of inflation on the economy may be even more important because it may be hard for governments to deal with inflation without independent monetary policy.

- Gross fixed capital formation as \% of GDP: This measure aims to test whether the use of funds has influence on default risk. Higher capital formation is supposed to decrease default risk because it could lead to higher productivity and higher economic growth in the future. Thus, a higher future ability to make debt service payments is to be expected which should decrease the default risk.

- Trade balance as \% of GDP: While the overall state of the economy is vital, several studies find external sector indicators to be significant,too. The first indicator is the difference between exports and imports over GDP. However, this variable may influence sovereign yield spreads and the market perception in both directions. For instance, higher trade balance is expected to lead lower default risk since that it is indication of high competitiveness of the economy as well as of ability to get more funding for debt serving. While negative relationship can be considered as long-term or solvency issues.

- Openness as \% of GDP: Second external sector indicator is openness which is measured as the sum of exports and imports over GDP. The literature on the direction of the openness' influence on yield spreads points out different approaches. First one based on the willingto-pay literature. Accordingly, countries that do not serve their payment obligations are punished by the disruption of trade and capital flows. Thus, more open countries are likely to pay their dues, having lower default risks. On the other hand, spill-over literature argues that economies that are more open are more inclined to sudden shift in global risk appetite or external shocks in the world economy. Thus, this increases their default risks and yield spreads in time of crisis.

- Terms of Trade: A third variable related to the external sector used in the analysis is the change in the terms of trade index. An increase (decrease) of the terms of trade means that 
(average) export prices in relation to (average) import prices increase (decrease). Since almost all countries in the sample uses the same currency, the differences between countries result from changes in their export prices. An increase of terms of trade may decrease default risk and, thus, yield spreads since it favors the economy and makes it easier to collect funds for debt servicing.

Liquidity indicators: In addition to variables related to the market perception of countriesŠ default risk discussed so far, the market liquidity also may influence sovereign yield spreads. The influence of liquidity for EMU bond markets is controversial in the literature. Some emphasize the importance of liquidity, while others find it to be insignificant. Several indicators are used in the literature. For single bond issues, one can observe bid-ask-spreads and the face value of outstanding debt. On an aggregated level for the country, the entire outstanding debt can serve as an indicator for the depth of the countryšs bond market. Due to the lack of data, bid-ask spreads are not employed while there are several studies such as Ejsing and Sihvonen (2009), and Korajczyk and Sadka (2008), show that bid-ask-spreads and other liquidity measures are closely related. Two aggregated measures are proposed:

- Total outstanding debt: The more liquid is the individual bond market, the lower the liquidity premium.

- Total government debt as \% of total government debt in the sample

Global risk indicators: On top of country specific variables, variables related to global monetary conditions as well as market sentiments are reported to be main drivers of the yield spreads in the literature. In this sense, US interest rate is considered as indicator of the international financing conditions. It reflects global financing costs, thus supposed to determine market perception of default risk and spreads. Secondly, another global driver of the spreads is considered to be important is influence of market sentiments which is defined as the tendency to invest in risky assets. The spread for risky US corporate bonds over US treasury bond is considered as the measurement of the market sentiments.

- US interest rate with 1 year maturity: A higher US rate is likely to increase the yield spreads. 
- Market sentiment: BBB rates US corporate bond spreads to US treasuries. Higher corporate bond spreads is likely to lead to higher sovereign yield spreads.

Governance indicators: Employing only macroeconomic fundamentals to explain spreads does not capture whole picture on the determinants of the spreads. Especially, for the emerging economies, incorporating political risk is found to be significant in the literature. Given that this study focuses on the developed economies, rather than concentrating on aggregate political risk indices, market perception of the differences on governance and regulatory is more relevant. In this sense, the Worldwide Governance Indicators (WGI) are employed ${ }^{5}$.

- Government effectiveness: It reflects perceptions of the ability of the government to formulate and implement sound policies and regulations that permit and promote private sector development. The governance indicators are expected to have a negative sign as higher governance quality indicates better institutions, political regime and economic development and social stability, thus this decreases default probability.

- Regulatory quality: It reflects perceptions of the quality of public services, the quality of the civil service and the degree of its independence from political pressures, the quality of policy formulation and implementation, and the credibility of the government's commitment to such policies.

\section{Econometric framework}

In line with [9], this econometric approach is based on the estimation of gravity type of model with combination of cross-sectional and time-series dimension. Moreover, intercept approach in panel framework is adopted: Intercepts change across the units while the coefficients

\footnotetext{
${ }^{5}$ This statistics reports aggregate and individual governance indicators for 213 economies over the period 1996Ű2010, for six dimensions of governance:1) voice and accountability 2) political stability and absence of violence 3) government effectiveness 4) regulatory quality 5)rule of law 6) control of corruption. The individual data sources underlying the aggregate indicators are collected from a variety of survey institutes, think tanks, non-governmental organizations, and international organizations
} 
are fixed. Since that the T dimension which is dictated by data availability is rather short, we work with standard micro panel framework. The general model can be defined as such:

$$
y_{i j t}=\alpha+\beta^{\prime} X_{i j t}+\delta_{t}+\mu_{i j}+\epsilon_{i j t}
$$

where $\alpha$ represents overall constant in the model, $\delta_{t}$ stands for period-specific effects while $\mu_{i j}$ is cross-sectional effects. And $\epsilon_{i j t}$ are error terms for cross-sectional units while the explanatory variables are $X_{i j t}$.

In addition, by including dynamics in the model it is possible to take care of serial dependence directly, addressing the persistence of correlations in the residuals. However, dynamic panel model with individual effects induces Nickell [33] bias ${ }^{6}$. On the other hand, there are two issues need to be addressed. First of all, we work with FGLS to treat cross sectional dependence while endogeneity is addressed with GMM. Regarding the second issue, fiscal variables are cyclically responsive to the interest rates. For instance, during the recessions, fiscal deficits increase while long-term interest rates fall due to monetary easing. So, there is spurious reverse correlation between fiscal variables and the long-term interest rates. The literature suggests either to work with the projected fiscal variables to anticipate the forward looking behavior of the markets or work with GMM.

\subsection{The model-reduced-form equation}

Yield differentials between sovereign debt borrowers are mainly determined by four factors: 1) expectations of exchange rate fluctuations 2) differences in tax-regime 3) differences in default/credit risk 4) differences in market liquidity. For the European sovereign debt markets, credit and liquidity risks are main drivers of the yield differentials, given the elimination of currency risk in 1999 and relaxation in tax regime on bond issuance during 1990s. The preEMU literature has pointed out that with the elimination of currency risk, yield spreads would mainly reflect default risk while market participants as well as policy makers have argued that EMU yield differentials were due to mostly liquidity factors till recent economic crisis.

\footnotetext{
${ }^{6}$ Nickell(1981) argues the bias increases with the ratio of $\mathrm{N}$ over T. Given the number of pairs (91) compared with the period of 15 years, potential bias should be limited in this empirical study.
} 
To correct the foreign exchange component for pre-EMU period as well as for non-EMU members, the literature broadly indicates three potential measures: 1) long-term bonds issued by the same supra-national organization such as World Bank, 2) long-term bonds issued by the private sector and 3) the fixed interest rates on swap contracts. Favero, Giavazzi, and Spaventa [20] explicitly discuss measures of the component of yield differentials excluding exchange rate risks. Accordingly, it is suggested to measure yield differentials excluding exchange rate risks through comparing the yields of assets issued by two different states in two different currencies (for instance, one in French frank, the other in German marks) or by comparing the yield spreads in the same currencies and with the same maturity issued by the same non-government agency or issued by two comparable issuers.

Alesina, Broeck, Prati, Tabellini, Obstfeld, and Rebelo [1] study the interest rates on public and private financial instruments denominated in the same currencies in 12 OECD countries. Giovannini and Piga [22] work with the interest rate on an Italian government bond issued in Eurodollar market and a comparable World Bank bond issued in the global market. Arnold and Lemmen [5], Blanco [12], Codogno, Favero, and Missale [16], Favero, Giavazzi, and Spaventa [20] compare government bond yield differentials and interest rate swap (IRS) differentials.

Among the abovementioned three options, supra-national issues are by definition default risk-free while they are less liquid and deep than that for sovereign bonds. Corporate bonds are relatively more volatile and are not default risk-free. However, interest swap rates have its own drawbacks, too. Swaps are too cyclical to the financial conditions. Although it is not a perfect measure, the interest rate swap contracts are employed as the indicator of the exchange rate risk between the parties ${ }^{7}$.

So, denote that $I_{i, 10}$-10-year yield on sovereign bonds of country $i$ and $I R S_{i, 10}$-10-year interest rate swap rate of currency i. And given that the elimination of differences in tax treatment, the

\footnotetext{
${ }^{7}$ The fixed interest rate swap price accounts for the counterparty risk, the liquidity, the market risk of the product as well as the exchange rate risk. Thus, the spreads between the 10-year swap rate of country i over country j bears only the exchange rate risk while other three components are canceled out. For further discussion, please see Gómez-Puig [23].
} 
yields are determined:

$$
I_{i, 10}=f\left(D R_{i, 10}, L_{i, 10}, E R_{i, 10}\right)
$$

$D R_{i, 10}$-Default risk of country i 10 -year sovereign bonds, $L_{i, 10}$-Liquidity of country i 10 -year sovereign bonds, $E R_{i, 10}$-Exchange rate risk of currency i over a 10-year horizon. Therefore, the 10-year yield differential of country i over country $j$ will be:

$$
\text { Yieldspread }_{i j, t}=f\left(\left[D R_{i, 10}-D R_{j, 10}\right]_{t},\left[L_{i, 10}-L_{j, 10}\right]_{t},\left[E R_{i, 10}-E R_{j, 10}\right]_{t}\right)
$$

Then, approximating:

$$
\text { Interest Rate } \operatorname{Swap}_{i, 10}-\text { Interest Rate } \mathrm{Swap}_{j, 10}=E R_{i, 10}-E R_{j, 10}
$$

Define the adjusted spread as the difference between the total yield differential and swap rate differential:

$$
\begin{aligned}
\operatorname{AdjSpread}_{i j, 10} & =\left[I_{i, 10}-I_{j, 10}\right]_{t}-\left[I R S_{i, 10}-I R S_{j, 10}\right]_{t} \\
& =f\left(\left[D R_{i, 10}-D R_{j, 10}\right]_{t},\left[L_{i, 10}-L_{j, 10}\right]_{t}\right)
\end{aligned}
$$

\section{Static panel model}

Therefore, the first panel model with the abovementioned indicators will be:

$$
\operatorname{AdjSpread}_{i j t}=y_{i j t}=\alpha_{0}+\beta_{0}^{\prime} X_{i j t}+\delta_{t}+\mu_{i j}+\epsilon_{i j t}
$$

where $\alpha_{0}$ represents overall constant in the model, $\delta_{t}$ stands for period-specific effects while $\mu_{i j}$ is cross-sectional effects. And $\epsilon_{i j t}$ are error terms for cross-sectional units while the explanatory variables, $X_{i j t}$ are the differentials between the economic, liquidity as well as global risk factors and governance indicators listed in the previous section.

\section{Dynamic panel model}

In the second estimated model, the lagged dependent variable is introduced to allow a slow dynamic adjustment to a long-term equilibrium value of the spreads. Given that some indicators such as default or governance indicators do not change drastically over 
time, dynamic model captures relative importance of the indicators in explaining spreads, rather than the levels of yield differentials. Accordingly,

$$
y_{i j t}=\alpha_{0}+\rho_{0} y_{i j t-1}+\beta_{0}^{\prime} X_{i j t}+\delta_{t}+\mu_{i j}+\epsilon_{i j t}
$$

where $\alpha_{0}$ represents overall constant in the model, $\delta_{t}$ stands for period-specific effects while $\mu_{i j}$ is cross-sectional effects. And $\epsilon_{i j t}$ are error terms for cross-sectional units while the explanatory variables, $X_{i j t}$ are the differentials between the indicators.

\section{Non-linear dynamic panel model (non-linearity in terms of time)}

In this model specification, possible structural breaks in the coefficients are examined. Respectively,

$$
\begin{aligned}
y_{i j t}=\alpha_{0}+\rho_{0} y_{i j t-1}+\beta_{0}^{\prime} X_{i j t}+\operatorname{EMU}\left(\alpha_{1}+\beta_{1}^{\prime}\right. & \left.X_{i j t}\right) \\
& +\operatorname{Crisis}\left(\alpha_{2}+\beta_{2}^{\prime} X_{i j t}\right)+\lambda_{t}+\mu_{i j}+\epsilon_{i j t}
\end{aligned}
$$

where EMU is dummy variable for the period after EMU and Crisis is a dummy for the period after Lehman default in September 2008. Interacting these two dummies with the explanatory variables allows to test for structural breaks due to the the introduction of the euro and the 2008/2009 financial crisis. Finally, $X_{i j t}$ is a set of explanatory variables.

\section{Non-linear dynamic panel model (non-linearity in terms of country)}

Final model specification aims to address the question whether the response of the dependent variable to an explanatory variable changes with both pair countries being member of EMU: Do the EMU members pay higher or lower borrowing cost?

$$
\begin{aligned}
y_{i j t}=\alpha_{0}+\rho_{0} y_{i j t-1}+\beta_{0}^{\prime} X_{i j t}+ & \text { EMU-member }\left(\alpha_{1}+\beta_{1}^{\prime} X_{i j t}\right) \\
& + \text { non-EMU-member }\left(\alpha_{2}+\beta_{2}^{\prime} X_{i j t}\right)+\lambda_{t}+\mu_{i j}+\epsilon_{i j t}
\end{aligned}
$$

where EMU-member is dummy variable for the pairs which are both EMU members while non-EMU-member is a dummy for non-EMU member pairs. The aim of this analysis is to test for structural breaks due the EMU membership. Finally, $X_{i j t}$ is a set of explanatory variables. 


\section{Estimation and results}

\subsection{The data set}

For the empirical analysis, the data set contains data on all pairwise combinations in a panel of 14 countries, namely, Austria, Belgium, Finland, France, Germany, Greece, Ireland, Italy, Netherlands, Portugal, Spain which are member states of the EMU prior to the 2004 expansion as well as 3 non-EMU members such as Denmark, Sweden and United Kingdom. Note that Luxembourg is not considered due to the lack of data. The annual data covering between 1996-2011 is considered since the main motivation is to put some lights on the long-term determinants of sovereign debt yield spreads and how the markets prices default risks for the period within the EMU. The period analyzed is dictated by the data availability.

The dependent variable is the pairwise difference in the long-term interest rate (average) denominated in local currency of country $i$ and $j$. The interest rates are from the primary markets. As already been discussed, the exchange rate risks for pre-EMU period as well as non-EMU members are approximated by the interest rate swap differentials in order to focus on the default risk only. The right-hand-side variables of the model comprise economic, liquidity, global risk as well as governance indicators that are discussed in section 3 and summarized in Table 8 .

Table 9 shows the descriptive statistics while Table 10 reports correlations among these variables. The adjusted sovereign yield spreads range from $-13 \%$ to $+13 \%$ with near zero mean . The bond markets started to price fundamental macro variables right after the 2008/2009 crisis when those high spreads are observed. In other words, the divergence in the yield spreads among the 14 countries right after 2008 financial turmoil as shown in the Figure 1 is mainly driven by the spreads between the so-called soft-currency and the hard-currency economies. The long-run interest rates on Greek bonds jump to $15.75 \%$ in 2011 while the second highest rate is recorded by Portuguese bonds at $10.24 \%$ for 2011 . Those are followed by the Irish long-term interest rates at $9.6 \%$ in 2011. Finally, Spain as well as Italy stand out with higher borrowing cost compared with other sample countries with $5.42 \%$ and $5.44 \%$ in 2011 , respectively while the borrowing cost for the rest of sample countries range from 2\% to 4\% for 2011 (See Figure 2).

Pairwise correlation generally support the expected relationship between dependent vari- 
able and the independent variables. Accordingly, Table 10 reveals that the sovereign debt yield spreads are negatively related with differential budget balance ratio and positively related with differential government debt ratio. Note that the reduction in budget balance (larger budget deficits) leads an increase in the yield spreads. The differential GDP growth rate as well as the differential gross fixed investment ratio appear to have significant negative correlations with the yield spreads which is in line with prior expectations. Moreover, external sector indicators namely, differential trade balance ratio and openness turn out to be significant with negative signs. The literature points out the possibility of both sign directions for those indicators while another external sector indicator, annual terms of trade change is not significantly related with yield spreads. Furthermore, the liquidity indicators are also significantly related with the spreads, as the liquidity increases, the spreads decrease. Interestingly, global risk indicators, US short-term interest rates as well as market sentiment indicators are not related with the yield spreads. Thus, we expect those variables to be negligible in the regression analysis despite the fact that there are many studies suggest quiet the opposite. Finally, governance indicators are highly correlated with yield spreads with negative signs. Better quality in the governance pays off in terms of lower borrowing cost in the bond markets.

\subsection{Determinants of yield spreads}

\subsubsection{Benchmark results}

The determinants of sovereign debt yield spreads are estimated for the benchmark data sample covering 14 countries as well as the period of 1996-2012. We first regress equations (6) and (7) for the whole period while later the effects of EMU and financial crisis on risk pricing in sovereign bond markets are investigated through non-linear dynamic model in the equation (7). Finally, the possible non-linearity in the coefficients (in terms of country) is studied to trace out the effects of being EMU member.

It is well documented that the standard panel estimators become inconsistent in the presence of the cross section dependence. In this sense, Feasible GLS approach is applied to the models. However, it is argued that FGLS provides more efficient parameter estimates while standard error estimates from FGLS are extremely optimistic since standard error estimates are condi- 
tional on the estimated disturbance covariance. Thus, we employ different methods for GLS weights and coefficient covariance matrices. Cross-section weights for FGLS anticipate different variance for each cross-section while White cross-section method for coefficient covariance estimates is robust to cross-section heterogeneity and contemporenous correlation among units.

Table 1 and 2 report the estimate results of the first and second model specifications. In contrast to the estimated models of Table 1, the specification of Table 2 allow for some dynamics in the yield spreads through the inclusion of an $\mathrm{AR}(1)$ component. The dynamic specification is supported by the significant $\mathrm{AR}(1)$ term.

The results of FGLS for static model support the sign expectations for the whole explanatory variables except the budget ratio while the negative relationship between openness and yield spreads is detected. So, willingness-to-pay literature seems dominant in this empirical study as it is argued that more open countries are likely to pay their debts, thus having lower default risks. Whereas the spill-over literature advocates the opposite: More open countries are more vulnerable to sudden shift in global investment sentiments, thus having higher default risks. On the global risk factor indicator, most of the studies on the determinants of EU-zone sovereign yield spreads find out the importance of the global financing conditions. However, in this empirical setup, the US short-term interest rates do not have any affects on the yield spreads while the positive relationship is in line with expectations.

On the budget balance ratio, the reduction in budget balance (increase in the budget deficit) is expected to increase the yield spreads. Thus, the results do not support negative relationship, but positive relationship. Moreover, differential budget ratios turn out to be insignificant in determining the long-term sovereign yield spreads. First three columns of the Table 1 present the different measurements for the fiscal outlook such as primary budget deficit ratios and primary budget expenditure ratios to avoid potential endogeneity bias in the estimation results, which could be affected from the fact that the current deficit or expenditure figures include government interest payments. However, those measurements can not provide any remedy, either. The former still indicates positive relationship between the budget deficit and yield spreads while the primary budget expenditure ratios also indicate counterintuitive sign. One possible expla- 
Table 1: Feasible generalized least square estimation for static model

\begin{tabular}{|c|c|c|c|c|c|c|}
\hline & (1) & (2) & (3) & (4) & (5) & (6) \\
\hline \multirow[t]{2}{*}{ budget_ratio } & 0.053 & & & & & \\
\hline & $(0.049)$ & & & & & \\
\hline \multirow[t]{2}{*}{ debt_ratio } & $0.034^{* *}$ & $0.032^{* *}$ & $0.037^{* * *}$ & $0.025^{* *}$ & & $0.026^{* * *}$ \\
\hline & $(0.016)$ & $(0.014)$ & $(0.017)$ & $(0.011)$ & & $(0.009)$ \\
\hline \multirow[t]{2}{*}{ GDP_growth } & $-0.138^{* *}$ & $-0.139^{* * *}$ & $-0.153^{* * *}$ & $-0.106^{* * *}$ & $-0.113^{* * *}$ & $-0.075^{* *}$ \\
\hline & $(0.055)$ & $(0.052)$ & $(0.055)$ & $(0.034)$ & $(0.040)$ & $(0.034)$ \\
\hline \multirow[t]{2}{*}{ CPI } & 0.061 & 0.052 & 0.042 & $0.065^{*}$ & 0.051 & \\
\hline & $(0.039)$ & $(0.035)$ & $(0.036)$ & $(0.037)$ & $(0.032)$ & \\
\hline \multirow[t]{2}{*}{ GFI_ratio } & $-0.100^{* * *}$ & $-0.098^{* * *}$ & $-0.088^{* * *}$ & $-0.088^{* * *}$ & $-0.119^{* * *}$ & $-0.054^{* * *}$ \\
\hline & $(0.037)$ & $(0.034)$ & $(0.029)$ & $(0.028)$ & $(0.043)$ & $(0.022)$ \\
\hline \multirow[t]{2}{*}{ Openness } & -0.006 & -0.006 & -0.010 & -0.009 & $-0.012^{*}$ & \\
\hline & $(0.001)$ & $(0.006)$ & $(0.007)$ & $(0.006)$ & $(0.007)$ & \\
\hline \multirow[t]{2}{*}{ liquidity } & $-0.002^{* *}$ & $-0.002^{* *}$ & $-0.002^{* *}$ & $-0.001^{* *}$ & $-0.001^{* *}$ & $-0.001^{* * *}$ \\
\hline & $(0.001)$ & $(0.000)$ & $(0.000)$ & $(0.001)$ & $(0.000)$ & $(0.001)$ \\
\hline \multirow[t]{2}{*}{ us_short_int } & 0.007 & 0.01 & 0.007 & 0.006 & 0.004 & \\
\hline & $(0.016)$ & $(0.016)$ & $(0.014)$ & $(0.012)$ & $(0.012)$ & \\
\hline \multirow[t]{2}{*}{ gov_effectiveness } & -0.394 & -0.385 & -0.439 & -0.225 & -0.143 & \\
\hline & $(0.284)$ & $(0.265)$ & $(0.273)$ & $(0.155)$ & $(0.122)$ & \\
\hline \multirow[t]{2}{*}{ prim_bdgt_ratio } & & 0.054 & & & & \\
\hline & & $(0.041)$ & & & & \\
\hline \multirow[t]{2}{*}{ prim_expnd_ratio } & & & -0.063 & & & \\
\hline & & & $(0.042)$ & & & \\
\hline \multirow[t]{2}{*}{ Lg_debt_ratio } & & & & & $0.597^{* *}$ & \\
\hline & & & & & $(-0.245)$ & \\
\hline \multirow[t]{2}{*}{ Constant } & $-0.266^{*}$ & $-0.281^{*}$ & -0.039 & -0.101 & 0.115 & -0.293 \\
\hline & $(0.159)$ & $(0.160)$ & $(0.124)$ & $(0.108)$ & $(0.115)$ & $(0.094)$ \\
\hline Observations & 1,456 & 1,456 & 1,456 & 1,456 & 1,456 & 1,456 \\
\hline $\mathrm{R}$ squared & 0.596 & 0.598 & 0.601 & 0.568 & 0.522 & 0.472 \\
\hline \# of pairs & 91 & 91 & 91 & 91 & 91 & 91 \\
\hline Cross section FE & Yes & Yes & Yes & Yes & Yes & Yes \\
\hline Time FE & No & No & No & No & No & No \\
\hline GLS weights & CSW & CSW & CsW & CsW & CsW & CSW \\
\hline Coef. covar. method & White CS & White CS & White CS & White CS & White CS & White CS \\
\hline
\end{tabular}

nation of the spurious positive correlation is due to the cyclical responses of fiscal variables to interest rates. If the automatic fiscal stabilizers raise the budget deficits during the recessions, while at the same time long-term interest rates fall due to monetary easing, deficits and interest 
Table 2: Feasible generalized least square estimation for for dynamic model

\begin{tabular}{|c|c|c|c|c|c|c|}
\hline & (1) & (2) & (3) & (4) & (5) & (6) \\
\hline \multirow[t]{2}{*}{ lagged_adjspread } & $0.967^{* *}$ & $0.960^{* *}$ & $0.952^{* *}$ & $0.994^{* *}$ & $1.014^{* *}$ & $0.963^{* *}$ \\
\hline & $(0.393)$ & $(0.401)$ & $(0.401)$ & $(0.417)$ & $(0.457)$ & $(0.407)$ \\
\hline \multirow[t]{2}{*}{ budget_ratio } & $0.051^{*}$ & & & & & \\
\hline & $(0.030)$ & & & & & \\
\hline \multirow[t]{2}{*}{ debt_ratio } & $0.033^{* * *}$ & $0.029^{* * *}$ & $0.034^{* * *}$ & $0.024^{* * *}$ & & $0.023^{* *}$ \\
\hline & $(0.010)$ & $(0.009)$ & $(0.010)$ & $(0.007)$ & & $(0.006)$ \\
\hline \multirow[t]{2}{*}{ GDP_growth } & $-0.065^{* * *}$ & $-0.059^{* * *}$ & $-0.066^{* * *}$ & $-0.044^{* * *}$ & $-0.045^{* * *}$ & $-0.057^{* *}$ \\
\hline & $(0.021)$ & $(0.019)$ & $(0.020)$ & $(0.014)$ & $(0.016)$ & $(0.015)$ \\
\hline \multirow[t]{2}{*}{ CPI } & 0.002 & 0.003 & -0.002 & 0.023 & 0.018 & \\
\hline & $(0.033)$ & $(0.032)$ & $(0.030)$ & $(0.033)$ & $(0.033)$ & \\
\hline \multirow[t]{2}{*}{ GFI_ratio } & -0.023 & -0.019 & -0.011 & -0.008 & $-0.036^{*}$ & \\
\hline & $(0.021)$ & $(0.021)$ & $(0.006)$ & $(0.017)$ & $(0.018)$ & \\
\hline \multirow[t]{2}{*}{ Openness } & -0.009 & $-0.010^{*}$ & $-0.011^{*}$ & $-0.010^{* *}$ & $-0.012^{* *}$ & \\
\hline & $(0.006)$ & $(0.006)$ & $(0.006)$ & $(0.004)$ & $(0.005)$ & \\
\hline \multirow[t]{2}{*}{ liquidity } & $-0.002^{* * *}$ & $-0.002^{* *}$ & $-0.002^{* *}$ & $-0.001^{* *}$ & $-0.001^{* *}$ & $-0.001^{* *}$ \\
\hline & $(0.000)$ & $(0.000)$ & $(0.000)$ & $(0.000)$ & $(0.000)$ & $(0.000)$ \\
\hline \multirow[t]{2}{*}{ us_short_int } & 0.024 & 0.022 & 0.017 & 0.012 & 0.014 & \\
\hline & $(0.017)$ & $(0.017)$ & $(0.015)$ & $(0.014)$ & $(0.015)$ & \\
\hline \multirow[t]{2}{*}{ gov_effectiveness } & $-0.431^{* *}$ & $-0.397^{* *}$ & $-0.440^{* *}$ & $-0.276^{* *}$ & $-0.215^{*}$ & $-0.266^{* *}$ \\
\hline & $(0.202)$ & $(0.188)$ & $(0.187)$ & $(0.130)$ & $(0.110)$ & $(0.115)$ \\
\hline \multirow[t]{2}{*}{ prim_bdgt_ratio } & & 0.039 & & & & \\
\hline & & $(0.026)$ & & & & \\
\hline \multirow[t]{2}{*}{ prim_expnd_ratio } & & & $-0.045^{*}$ & & & \\
\hline & & & $(0.024)$ & & & \\
\hline \multirow[t]{2}{*}{ Lg_debt_ratio } & & & & & $0.583^{*}$ & \\
\hline & & & & & $(0.342)$ & \\
\hline \multirow[t]{2}{*}{ Constant } & $-0.264^{*}$ & $-0.237^{*}$ & -0.072 & -0.124 & 0.023 & $-0.207^{* *}$ \\
\hline & $(0.136)$ & $(0.130)$ & $(0.139)$ & $(0.099)$ & $(0.099)$ & $(0.049)$ \\
\hline Observations & 1,431 & 1,431 & 1,431 & 1,431 & 1,431 & 1,431 \\
\hline R squared & 0.773 & 0.762 & 0.766 & 0.731 & 0.687 & 0.72 \\
\hline \# of pairs & 91 & 91 & 91 & 91 & 91 & 91 \\
\hline Cross section FE & Yes & Yes & Yes & Yes & Yes & Yes \\
\hline Time FE & No & No & No & No & No & No \\
\hline GLS weights & CSW & CSW & CSW & CSW & CSW & CSW \\
\hline Coef. covar. method & White CS & White CS & White CS & White CS & White CS & White CS \\
\hline
\end{tabular}

CSW-Cross section weights and ${ }^{* * *} \mathrm{p}<0.01$, ${ }^{* *} \mathrm{p}<0.05,{ }^{*} \mathrm{p}<0.10$

rates may be negatively correlated.

In the static model, differential annual CPI change, differential openness as well as government effectiveness also turn out be insignificant. Since those variables have no affects on the 
yield spreads in all estimates, we drop the variables and reestimate the static model with differential debt ratio, gdp growth rates, gross fixed capital formation ratio and liquidity. The results are presented in the column (6) of Table 1. Accordingly, a debt ratio differential of 50\% among the parties results in an increase of $1.30 \%$ in the yield spread while performing $1 \%$ higher economic growth relative to the reference country decreases yield spreads by $0.08 \%$. The gross fixed capital formation ratio is the only measure to indicate whether the use of funds has influence on the borrowing cost or not. Respectively, a gross fixed capital formation ratio differential by $10 \%$ causes a decline in yield spread of $0.54 \%$. Finally, an increase in the bond market size by 100 million euro causes a reduction of the yield spreads by $0.12 \%$.

In the dynamic model, the autoregressive component turns out be significant and stable as it is less than 1 . Only in the estimation with log debt ratio in the column (5), the coefficient exceeds the unity. However, it is very close to one, indicating high persistence in the yield spreads. The budget related variables such as budget balance, primary budget balance and primary expenditure ratios post counterintuitive sign as in the static model. Thus,we focus on the debt outlook as an indicator of government fiscal performance. Global risk factors do not effect the cost of borrowing for this period while the differential annual CPI change as well as the differential openness also post insignificant values. However, governance indicators become significant in the dynamic model while the gross fixed capital formation ratio registers insignificant coefficient. Following the exclusion of the insignificant independent variables, we reestimate the dynamic model with differential debt ratio, gdp growth rates, liquidity as well as government effectiveness and results are presented in the column (6) of Table 2. Respectively, short-term coefficients can be interpreted as follows: A debt ratio differential of 50\% among the parties results in an increase of $1.15 \%$ in the yield spreads while growing $1 \%$ higher relative to the reference country decreases yield spreads by $0.06 \%$. Furthermore,an increase in the bond market size by 100 million euro causes a reduction of the yield spreads by $0.10 \%$. Note that governance indicator is index rather than ratio which is the feature of most explanatory variables. Estimate of governance ranges from approximately -2.5 (weak) to 2.5 (strong) governance performance. Thus, one unit increase in differential governance indicator between two countries decreases 
the yield spreads among those countries by $0.27 \%$.

The lower panel of Table 3 shows the variables that are interacted with EMU dummy and Crisis dummy to test for structural breaks in the coefficients after the start of EMU as well as the crisis. The first column of Table 3 summarize the benchmark results while the second column indicates the robustness of the results as the regression is entertained without the interacted variables with the EMU dummy. The third column cooperates the budget ratio variable instead of debt ratio to analyze the fiscal performance in the presence of the structural breaks. Still, the debt ratio is more appropriate to work with for the fiscal performance measurement. While the pricing direction of risks related to the relevant factors remains unchanged with EMU membership and the crisis period, the relationship between the risk factors and bond yield spreads have changed significantly across the subperiods. In other words, the differential debt ratios are the only factor to determine the long-term sovereign debt yield spreads, but with much lower marginal effects during the pre-EMU period whereas the other variables turn out to be insignificant. The most important point of the non-linear dynamic model estimation is that all risk factors become insignificant with the introduction of EMU while the differences in economic indicators, liquidity as well as governance indicators have been revalued by the markets after the 2008/2009 financial crisis. Final remark related to the GDP growth rate and governance indicator: the marginal effects of the differential gdp growth rates on the sovereign yield spreads intensify with the crisis period. $(-0.20$ during the crisis versus -0.06 during the whole sample period) while the marginal effects of the differential in government effectiveness almost double during the crisis ( -0.40 during the crisis versus -0.27 of the whole sample period).

Lastly, Table 4 summarizes the results of the non-linear dynamic model of the equation (9). The aim of this analysis is to investigate whether the relationship between independent variables and bond yield spreads changes due to both parties being members of EMU. Note that the interaction variables are constructed in an additive way. For instance, the effect of one percent differential of an explanatory variable between pair countries if both pairs are EMU members is the sum of the coefficients on the relevant variables, if all two variables are significant. Among the EMU members, the pricing risk related to an increase in the debt ratio remains unchanged 
and moreover its marginal effects intensify while among the non-EMU members, the relationship between the debt ratio and bond yield spreads has changed significantly. The results of a Wald test of the hypothesis that sum of the coefficients on debt ratio and debt ratio*EMU is zero is rejected at standard significance levels as shown in Table 5. This indicates that markets price fiscal indebtedness more among the EMU members than among the non-EMU members. Interestingly, the individual significance of the differential debt ratio interacted with non-EMU member dummy is statistically significant with negative sign. Thus, the markets price the deterioration in the debt outlook among non-EMU countries far less than among EMU members. However, the result of a Wald test of the hypothesis that sum of the coefficients on debt ratio and debt ratio*non-EMU is zero is failed to be rejected at $10 \%$ significance level. Moreover, the marginal effects of an increase in the differential debt ratios on the sovereign yield spreads among the non-EMU members become statistically insignificant.

\subsection{Robustness analysis}

We check the robustness of the results by employing the different econometric techniques such as Generalized Methods of Moments (GMM) as well as focusing on the subsample countries to test whether the results are robust to different specifications. First, the dynamic panel model is estimated with GMM estimators developed by Arellano and Bond [3] rather than FGLS which allows the presence of heteroscedasticity across panels. Secondly, analysis for the subsample countries excluding PIIGS (Portugal, Italy, Ireland, Greece and Spain) is conducted for the dynamic panel model.

\subsubsection{GMM estimation}

In this section, the model specification (5) is reestimated by GMM approach to check whether the results are robust to specific econometric method. FGLS allows for the presence of heteroscedasticity across panels to control for greater variation across pairs while GMM controls for endogeneity. Table 6 reports the estimate results of the model specifications in the equation (7). Respectively, the first column re-reports the benchmark results while other three columns present the results varying according to the different choices of instrumental variables. 
Using GMM estimation requires many specification choices. The lower panel of Table 6 also shows the details on those choices. Arellano and Bond [3] ${ }^{8}$ estimation transforms the regressors by differencing and use GMM while system GMM builds system of two equations, the original one and transformed one to allow more instrumental variables. We work with "difference GMM" while GMM weights are Arellano-Bond 2-step estimation. In the first step the error terms are assumed to be independent and homoscedastic across countries and over time. In the second step, the residuals obtained in the first step are used to construct a consistent estimate of the variance-covariance matrix, thus relaxing the assumptions of independence and homoscedasticity while coefficient error terms are corrected and they are robust. Final crucial specification is the choice of instrumenting variables and lags to be used in the estimation. The instrumental space is conducted by the past values of dependent as well as independent variables.

It is generally suggested that every regressor should be present in the instrumental matrix in some form: either level or transformed form. For instance, if the regressors are endogeneous, standard way to work is lags 2 and deeper, if they are predetermined, standard treatment is to use lags 1 and deeper and if a regressor is strictly exogenous,then insert that variable in the matrix. However, many instruments can overfit endogenous variables. Thus, one should be careful to check whether the number of instruments exceeds the number of units or not.

Accordingly, the reported J-statistics in the Table 6 can be used to construct the Sargan test of over-identifying restrictions while the instrument ranks are greater than the number of estimated coefficients of 5 . Under the null hypothesis that the over-identifying restrictions are valid, the Sargan statistic is distributed as $\chi_{(p-k)}$, where $\mathrm{p}$ is the number of instrumental rank and $\mathrm{k}$ is the number of estimated coefficients. The p-values of the Sargan tests are reported at the last line of the table. In this respect, treating all regressors as endogenous variable fails to pass the overidentification test and these results are presented in the last column of the table.

\footnotetext{
${ }^{8}$ The Arellano and Bond [3] and Arellano and Bover [4] dynamic panel estimators based on the assumption of small $\mathrm{T}$ and large $\mathrm{N}$ panel structure, linear functional relationship, dynamic single left-hand variable, possible endogeneity in the independent variables, fixed individual effects and heteroskedasticity and autocorrelation within individuals,but not across units.
} 
While only treating the lagged dependent variable as predetermined but the other regressors exogenous also rejects the validity of overidentification.

In summary, the results of the second GMM specification support the key results from the previous analysis: Differential debt ratio, gdp growth rates, liquidity as well as governance indicators are significantly and robustly correlated to the sovereign yield spreads. The $\mathrm{p}$ value of Sargan statistic is 0.66 , thus the null hypothesis of the validity of overidentification is not rejected.

\subsubsection{Subsample analysis for the sample countries: Hard currency versus soft currency countries}

Second robustness check involves the revaluation of the dynamic panel model for the subsample countries excluding PIIGS (Portugal, Italy, Ireland, Greece and Spain). Equation (5) is reestimated using FGLS as well as GMM for the relevant sample. The results are reported in Table 7. Despite the fact that the results of individual significance tests are sensitive to the choice of coefficient covariance estimation method ${ }^{9}$, the signs of coefficients remain the same as well as the magnitudes of coefficients do not vary drastically, ranging within an interval. Accordingly, sovereign yield spreads are positively related to differential government debt ratio while negatively related to relative economic growth performance, differential liquidity of individual debt markets as well as governance quality.

\section{Conclusion}

Using pairwise combination in a panel of 14 European economies, namely 11 EMU members and 3 non-EMU members, from 1996 to 2011, this paper has investigated the long-term determinants of sovereign debt yield spreads. The potential drivers of sovereign debt yield spreads can be broadly classified into economic indicators, liquidity, global risk as well as governance indicators. We analyze which risk factor matters in the market perception of default risk and

\footnotetext{
${ }^{9}$ The second column presents the results with white diagonal whereas the third column shows the outcome with white period. The white period is the standard Arellano-Bond 2-step estimator standard errors (innovations have time series correlation structure that varies by units) whereas white diagonal is robust to cross-section heterogeneity as well as correlation among the units. Note that there is evidence in the literature that the standard errors for the two-step estimator may not be reliable.
} 
whether the introduction of EMU and the financial crisis in 2008/2009 have a significant impact on bond pricing.

The results show that sovereign yield spreads are sensitive to measures of differential government debt, economic growth performance, liquidity of the debt markets as well as governance quality. Interestingly, the differential debt ratios are the only factor to determine the long-term yield spreads before the emerge of EMU while markets seem to ignore fundamentals after the start of EMU. However, the differences in economic indicators, liquidity as well as governance indicators have been revalued by the markets after the financial crisis. We further investigate whether the relationship between independent variables and bond yield spreads changes due to both parties being members of EMU. Among the EMU members, the pricing risk related to an increase in debt ratio remains significant and its marginal effects intensify while among non-EMU members, bond yields respond to the debt ratio in an opposite direction. Moreover, all risk indicators become insignificant for non-EMU members.

The results of the dynamic panel model is robust to different estimation techniques such as GMM. Respectively, differential debt ratio, gdp growth rates, liquidity as well as governance indicators are significantly and robustly correlated to the sovereign yield spreads. Second robustness check involving the revaluation of the dynamic panel model for the subsample countries excluding PIIGS (Portugal, Italy, Ireland, Greece and Spain) further supports the claim that sovereign yield spreads are positively related to differential government debt ratio while negatively related to relative economic growth performance, differential liquidity of individual debt markets as well as governance quality.

\section{References}

[1] Alesina, A., M. D. Broeck, A. Prati, G. Tabellini, M. Obstfeld, and S. Rebelo (1992): “Default Risk on Government Debt in OECD Countries," Economic Policy, 7(15), pp. $427-463$.

[2] Ardagna, S., F. Caselli, And T. Lane (2004): “Fiscal Discipline and the Cost of Public 
Debt Service: Some Estimates for OECD Countries," Working Paper 10788, National Bureau of Economic Research.

[3] Arellano, M., And S. Bond (1991): “Some Tests of Specification for Panel Data: Monte Carlo Evidence and an Application to Employment Equations," Review of Economic Studies, 58(2), 277-97.

[4] Arellano, M., And O. Bover (1995): “Another look at the instrumental variable estimation of error-components models," Journal of Econometrics, 68(1), 29-51.

[5] ARnold, I., And J. Lemmen (2001): “The Vulnerability of Banks to Government Default Risk in the EMU," International Finance, 4(1), 101-25.

[6] Balassone, F., D. Franco, And R. Giordano (2004): “Market induced fiscal discipline: is there a fall-back solution for rule-failure?," .

[7] Barrios, S., P. IVersen, M. Lewandowska, and R. Setzer (2009): “Determinants of intra-euro area government bond spreads during the financial crisis," European Economy Economic Papers 388, Directorate General Economic and Monetary Affairs, European Commission.

[8] Bayoumi, T. A., M. Goldstein, And G. Woglom (1995): “Do Credit Markets Discipline Sovereign Borrowers? Evidence from US States," CEPR Discussion Papers 1088, C.E.P.R. Discussion Papers.

[9] BeINE, M., AND B. CANDELON (2011): “Liberalisation and stock market co-movement between emerging economies," Quantitative Finance, 11(2), 299-312.

[10] Bernoth, K., J. von Hagen, and L. Schuknecht (2003): “Sovereign risk premia in the European government bond market," ZEI Working Papers B 26-2003, ZEI - Center for European Integration Studies, University of Bonn.

[11] Bernoth, K., J. von Hagen, And L. SCHuKneCht (2012): “Sovereign risk premiums in the European government bond market," Journal of International Money and Finance, (0), -. 
[12] Blanco, R. (2001): “The Euro-Area Government Securities Markets. Recent Developments and Implications for Market Functioning," Banco de EspaÃśa Working Papers 0120, Banco de Espa Ãśa.

[13] Booth, L., G. Georgopoulos, And W. Hejazi (2007): “What drives provincial-Canada yield spreads?," Canadian Journal of Economics, 40(3), 1008-1032.

[14] BRAHMASRENE, T. (2006): “Measuring emerging stock market correlations utilizing the gravity model," Journal of Economics and Economic Education Research, 7(3).

[15] Canzoneri, M. B., R. E. Cumby, and B. T. Diba (2002): "Should the European Central Bank and the Federal Reserve be concerned about fiscal policy?," Proceedings, pp. 333-389.

[16] Codogno, L., C. FAvero, And A. Missale (2003): “Yield spreads on EMU government bonds," Economic Policy, 18(37), 503-532.

[17] DominiK, M. (2012): “Determinants of sovereign yield spreads in the Eurozone: A Bayesian approach," Journal of International Money and Finance, 31(3), 657 - 672.

[18] Elmendorf, D. W., ANd N. MankiW (1999): “Government Debt," Scholarly Articles 2643866, Harvard University Department of Economics.

[19] FAINI, R. (2006): “Fiscal policy and interest rates in Europe," Economic Policy, 21(47), 443489.

[20] FaVero, C., F. Giavazzi, and L. Spaventa (1998): “High Yields: The Spread on German Interest Rates," NBER Working Papers 5408, National Bureau of Economic Research, Inc.

[21] Gale, W. G., And P. R. Orszag (2005): “Budget Deficits, National Saving, and Interest Rates," .

[22] Giovannini, A., AND G. Piga (1992): “Understanding the High Interest Rates on Italian Government Securities," CEPR Discussion Papers 720, C.E.P.R. Discussion Papers.

[23] Gómez-Puig, M. (2008): "Monetary integration and the cost of borrowing," Journal of International Money and Finance, 27(3), 455-479. 
[24] Gruber, J. W., And S. B. KAMIN (2010): “Fiscal positions and government bond yields in OECD countries," International Finance Discussion Papers 1011, Board of Governors of the Federal Reserve System (U.S.).

[25] Haugh, D., P. Ollivaud, and D. Turner (2009): “What Drives Sovereign Risk Premiums?: An Analysis of Recent Evidence from the Euro Area," OECD Economics Department Working Papers 718, OECD Publishing.

[26] HeppKe-FalK, K. H., And F. P. HÃIJFNer (2004): “Expected budget deficits and interest rate swap spreads - Evidence for France, Germany and Italy," Discussion Paper Series 1: Economic Studies 2004,40, Deutsche Bundesbank, Research Centre.

[27] Laubach, T. (2009): "New Evidence on the Interest Rate Effects of Budget Deficits and Debt," Journal of the European Economic Association, 7(4), 858-885.

[28] Lemmen, J. J. (1999): “Managing Government Default Risk in Federal States,” Fmg special papers, Financial Markets Group.

[29] Lemmen, J. J., and C. A. Goodhart (1999): “Credit Risks and European Government Bond Markets: A Panel Data Econometric Analysis.," Eastern Economic Journal, 25(1), 77.

[30] LinnemanN, L., AND A. Schabert (2010): “Debt Nonneutrality, Policy Interactions, And Macroeconomic Stability," International Economic Review, 51(2), 461-474.

[31] LoOning, I. (2000): "Default premia on European government debt," Review of World Economics, 136, 259-283, 10.1007/BF02707688.

[32] Manganelli, S., AND G. WolswiJK (2009): “What drives spreads in the euro area government bond market?," Economic Policy, 24(58), 191-240.

[33] NiCKelL, S. (1981): "Biases in dynamic models with fixed effects," Econometrica: Journal of the Econometric Society, pp. 1417-1426.

[34] Oliveira, L., J. D. CURTO, And J. P. Nunes (2011): “The determinants of sovereign credit 
spread changes in the Euro-zone," Journal of International Financial Markets, Institutions and Money, (0), - .

[35] Poterba, J., and K. Rueben (1999): “State Fiscal Institutions and the U.S. Municipal Bond Market," in Fiscal Institutions and Fiscal Performance, pp. 181-208. National Bureau of Economic Research, Inc.

[36] SChuKnecht, L., J. vON HAgen, AND G. WOlsWiJK (2009): “Government risk premiums in the bond market: EMU and Canada," European Journal of Political Economy, 25(3), 371 - 384, $<$ ce:title $>$ The role of institutions in economic outcomes $</$ ce:title $>$.

[37] SgherRI, S., AND E. ZOLI (2009): "Euro Area Sovereign Risk During the Crisis," IMF Working Papers 09/222, International Monetary Fund.

[38] Thomas, L., AND D. WU (2009): “Long-term interest rates and expected future budget deficits: evidence from the term structure," Applied Economics Letters, 16(4), 365-368.

[39] von Hagen, J., L. Schuknecht, and G. Wolswijk (2011): “Government bond risk premiums in the EU revisited: The impact of the financial crisis," European Journal of Political Economy, 27(1), 36-43.

\section{Appendix}


Figure 1: Differential yield spreads

(a) Differential yield spreads

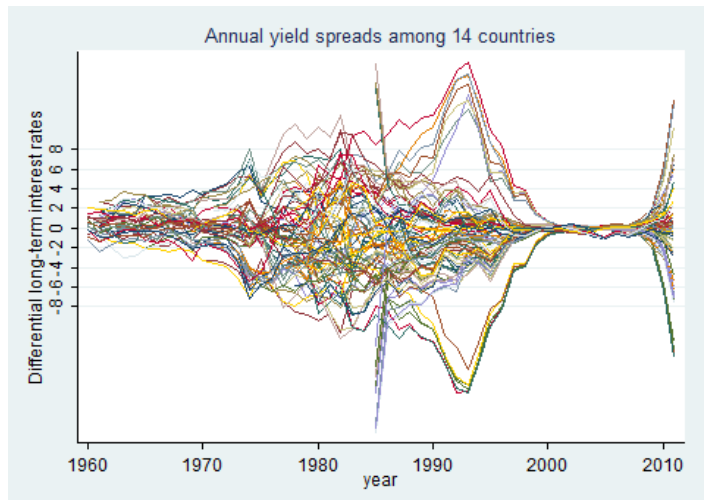

(b) Differential adjusted yield spreads

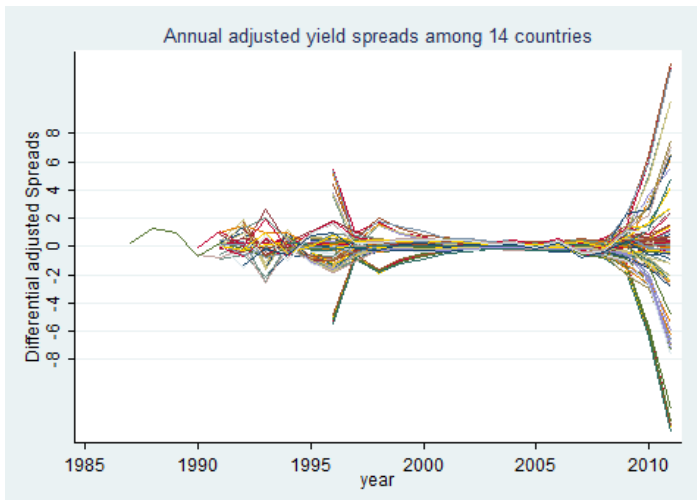

Source: AMECO

Figure 2: Differential adjusted yield spreads for the subsample countries

(a) Differential adjusted yield spreads

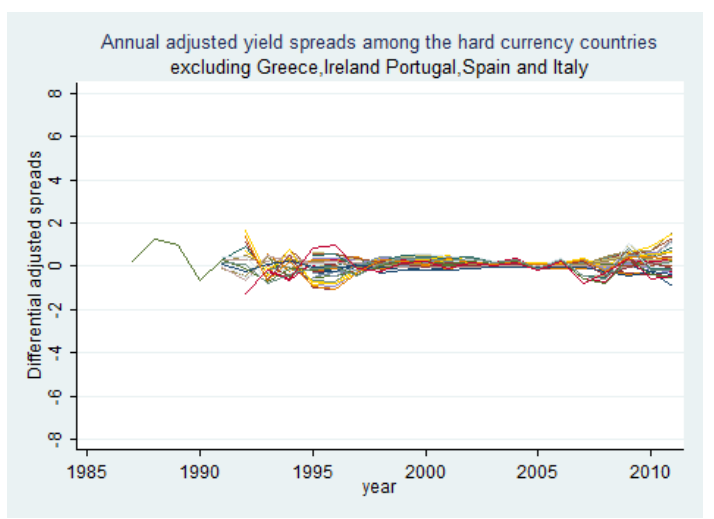

(b) Differential adjusted yield spreads

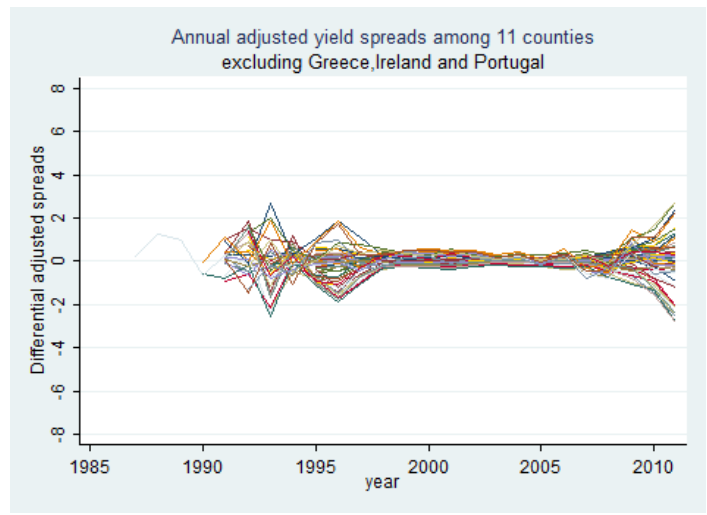

Source: AMECO 
Table 3: FGLS estimation for non-linear dynamic model-time

\begin{tabular}{|c|c|c|c|}
\hline & (1) & (2) & (3) \\
\hline lagged_adjspread & $\begin{array}{l}0.789^{* *} \\
(0.372)\end{array}$ & $\begin{array}{l}0.775^{* *} \\
(0.341)\end{array}$ & $\begin{array}{l}0.979^{* *} \\
(0.405)\end{array}$ \\
\hline budget_ratio & & & $\begin{array}{r}-0.016 \\
(0.077)\end{array}$ \\
\hline debt_ratio & $\begin{array}{r}0.016^{* * * *} \\
(0.004)\end{array}$ & $\begin{array}{r}0.017^{* * * *} \\
(0.005)\end{array}$ & \\
\hline GDP_growth & $\begin{array}{r}0.020 \\
(0.020)\end{array}$ & $\begin{array}{r}0.007 \\
(0.016)\end{array}$ & $\begin{array}{l}0.05^{* * *} \\
(0.015)\end{array}$ \\
\hline liquidity & $\begin{array}{c}-0.001 \\
(0.000)\end{array}$ & $\begin{array}{r}-0.001^{* * *} \\
(0.000)\end{array}$ & $\begin{array}{r}-0.001^{* *} \\
(0.000)\end{array}$ \\
\hline gov_effectiveness & $\begin{array}{r}0.025 \\
(0.001)\end{array}$ & $\begin{array}{r}-0.021 \\
(0.111)\end{array}$ & $\begin{array}{r}0.456 \\
(0.339)\end{array}$ \\
\hline Constant & $\begin{array}{r}-0.159^{* * * *} \\
(0.056)\end{array}$ & $\begin{array}{r}-0.170^{* * *} \\
(0.063)\end{array}$ & $\begin{array}{l}0.050^{* * *} \\
(0.025)\end{array}$ \\
\hline $\begin{array}{l}\text { EMU effect } \\
\text { budget_ratio }\end{array}$ & & & $\begin{array}{r}0.023 \\
(0.075)\end{array}$ \\
\hline debt_ratio & $\begin{array}{r}0.002 \\
(0.003)\end{array}$ & & \\
\hline GDP_growth & $\begin{array}{r}-0.014 \\
(0.017)\end{array}$ & & $\begin{array}{r}-0.014^{* * *} \\
(0.015)\end{array}$ \\
\hline liquidity & $\begin{array}{r}-0.000 \\
(0.000)\end{array}$ & & $\begin{array}{r}-0.000 \\
(0.000)\end{array}$ \\
\hline gov_effectiveness & $\begin{array}{r}-0.059 \\
(0.398)\end{array}$ & & $\begin{array}{r}-0.443 \\
(0.376)\end{array}$ \\
\hline $\begin{array}{l}\text { Crisis effect } \\
\text { budget_ratio }\end{array}$ & & & $\begin{array}{r}0.01 \\
(0.019)\end{array}$ \\
\hline debt_ratio & $\begin{array}{r}0.014^{* * *} \\
(0.003)\end{array}$ & $\begin{array}{r}0.014^{* * *} \\
(0.004)\end{array}$ & \\
\hline GDP_growth & $\begin{array}{r}-0.204^{* * *} \\
(0.005)\end{array}$ & $\begin{array}{r}-0.209^{* * *} \\
(0.005)\end{array}$ & $\begin{array}{r}-0.220^{* * *} \\
(0.054)\end{array}$ \\
\hline liquidity & $\begin{array}{r}-0.000^{* * * *} \\
(0.000)\end{array}$ & $\begin{array}{r}-0.000^{* * *} \\
(0.000)\end{array}$ & $\begin{array}{r}-0.001^{* * *} \\
(0.000)\end{array}$ \\
\hline gov_effectiveness & $\begin{array}{r}-0.404^{* * *} \\
(0.162)\end{array}$ & $\begin{array}{r}-0.409^{* * *} \\
(0.166)\end{array}$ & $\begin{array}{r}-1.056^{* * *} \\
(0.310)\end{array}$ \\
\hline Observations & 1,431 & 1,431 & 1,431 \\
\hline R squared & 0.793 & 0.791 & 0.739 \\
\hline Number of pairs & 91 & 91 & 91 \\
\hline Cross section FE & Yes & Yes & Yes \\
\hline Time FE & No & No & No \\
\hline GLS weights & CSW & CSW & CSW \\
\hline Coef. covar. method & White CS & White CS & White CS \\
\hline
\end{tabular}


Table 4: FGLS estimation for non-linear dynamic model-country

\begin{tabular}{|c|c|c|c|}
\hline & (1) & (2) & (3) \\
\hline lagged_adjspread & $\begin{array}{r}0.922^{* * *} \\
(0.402)\end{array}$ & $\begin{array}{r}0.928^{* * *} \\
(0.398)\end{array}$ & $\begin{array}{r}1.032^{* * *} \\
(0.462)\end{array}$ \\
\hline budget_ratio & & & $\begin{array}{r}-0.004 \\
(0.016)\end{array}$ \\
\hline debt_ratio & $\begin{array}{r}0.021^{* * *} \\
(0.007)\end{array}$ & $\begin{array}{r}0.018^{* * * *} \\
(0.005)\end{array}$ & \\
\hline GDP_growth & $\begin{array}{r}-0.049^{* * *} \\
(0.022)\end{array}$ & $\begin{array}{r}-0.064^{* * *} \\
(0.018)\end{array}$ & $\begin{array}{r}-0.056^{* * *} \\
(0.024)\end{array}$ \\
\hline liquidity & $\begin{array}{r}-0.001^{* * *} \\
(0.000)\end{array}$ & $\begin{array}{r}-0.001^{* * *} \\
(0.000)\end{array}$ & $\begin{array}{r}-0.000 \\
(0.000)\end{array}$ \\
\hline gov_effectiveness & $\begin{array}{l}-0.252^{*} \\
(0.141)\end{array}$ & $\begin{array}{r}-0.329 \\
(0.132)\end{array}$ & $\begin{array}{l}-0.355^{*} \\
(0.214)\end{array}$ \\
\hline Constant & $\begin{array}{r}-0.172^{* * *} \\
(0.055)\end{array}$ & $\begin{array}{r}-0.166^{* * *} \\
(0.043)\end{array}$ & $\begin{array}{r}-0.020 \\
(0.025)\end{array}$ \\
\hline $\begin{array}{l}\text { EMU members } \\
\text { budget_ratio }\end{array}$ & & & $\begin{array}{r}-0.009 \\
(0.016)\end{array}$ \\
\hline debt_ratio & $\begin{array}{r}0.007^{* * *} \\
(0.003)\end{array}$ & $\begin{array}{l}0.01^{* * *} \\
(0.004)\end{array}$ & \\
\hline GDP_growth & $\begin{array}{l}-0.022 \\
(0.024)\end{array}$ & & $\begin{array}{r}-0.030 \\
(0.033)\end{array}$ \\
\hline liquidity & $\begin{array}{r}-0.000 \\
(0.000)\end{array}$ & & $\begin{array}{l}-0.000 \\
(0.000)\end{array}$ \\
\hline gov_effectiveness & $\begin{array}{r}-0.114 \\
(0.134)\end{array}$ & & $\begin{array}{r}0.222 \\
(0.175)\end{array}$ \\
\hline $\begin{array}{l}\text { Non-EMU members } \\
\text { budget_ratio }\end{array}$ & & & $\begin{array}{r}-0.020 \\
(0.034)\end{array}$ \\
\hline debt_ratio & $\begin{array}{r}-0.025^{* * *} \\
(0.012)\end{array}$ & $\begin{array}{r}-0.022^{* * * *} \\
(0.012)\end{array}$ & \\
\hline GDP_growth & $\begin{array}{r}0.039 \\
(0.052)\end{array}$ & $\begin{array}{r}0.054 \\
(0.063)\end{array}$ & $\begin{array}{r}0.08 \\
(0.069)\end{array}$ \\
\hline liquidity & $\begin{array}{r}0.001^{* * *} \\
(0.001)\end{array}$ & $\begin{array}{r}0.001^{* * *} \\
(0.001)\end{array}$ & $\begin{array}{l}-0.000 \\
(0.000)\end{array}$ \\
\hline gov_effectiveness & $\begin{array}{r}0.037 \\
(0.613)\end{array}$ & $\begin{array}{r}0.113 \\
(0.590)\end{array}$ & $\begin{array}{r}0.393 \\
(0.610)\end{array}$ \\
\hline Observations & 1,431 & 1,431 & 1,431 \\
\hline R squared & 0.72 & 0.72 & 0.64 \\
\hline Number of pairs & 91 & 91 & 91 \\
\hline Cross section FE & Yes & Yes & Yes \\
\hline Time FE & No & No & No \\
\hline GLS weights & CSW & CSW & CSW \\
\hline Coef. covar. method & White CS & White CS & White CS \\
\hline
\end{tabular}


Table 5: Hypotheses tests

\begin{tabular}{lr}
\hline & Wald Test (p-values) \\
\hline$H_{0}$ : the sum of coefficients on debt_ratio and debt_ratio*EMU member is equal to zero & 0.00 \\
$H_{0}$ : the sum of coefficients on gdp_growth and gdp_rgrowth*EMU member is equal to zero & 0.00 \\
$H_{0}$ : the sum of coefficients on liquidity and liquidity*EMU member is equal to zero & 0.00 \\
$H_{0}$ : the sum of coefficients on governance and governance*EMU member is equal to zero & 0.00 \\
& 0.71 \\
$H_{0}$ : the sum of coefficients on debt_ratio and debt_ratio*Non-EMU member is equal to zero & 0.86 \\
$H_{0}$ : the sum of coefficients on gdp_growth and gdp_growth*Non-EMU member is equal to zero & 0.69 \\
$H_{0}$ : the sum of coefficients on liquidity and liquidity*Non-EMU member is equal to zero & 0.70 \\
$H_{0}$ : the sum of coefficients on governance and governance*Non-EMU member is equal to zero & \\
\hline
\end{tabular}

Table 6: Dynamic approach with GMM estimation

\begin{tabular}{|c|c|c|c|c|}
\hline & $\begin{array}{r}\text { FGLS } \\
(1)\end{array}$ & $\begin{array}{r}\text { GMM } \\
(2)\end{array}$ & $\begin{array}{r}\text { GMM } \\
\text { (3) }\end{array}$ & $\begin{array}{c}\text { GMM } \\
(4)\end{array}$ \\
\hline lagged_adjspread & $\begin{array}{l}0.963^{* *} \\
(0.407)\end{array}$ & $\begin{array}{r}0.590^{* * *} \\
(0.142)\end{array}$ & $\begin{array}{r}0.856^{* * *} \\
(0.002)\end{array}$ & $\begin{array}{l}0.900^{* *} \\
(0.135)\end{array}$ \\
\hline debt_ratio & $\begin{array}{l}0.023^{* *} \\
(0.006)\end{array}$ & $\begin{array}{r}0.073^{* * *} \\
(0.010)\end{array}$ & $\begin{array}{r}0.044^{* * *} \\
(0.000)\end{array}$ & $\begin{array}{l}0.039 * * \\
(0.006)\end{array}$ \\
\hline GDP_growth & $\begin{array}{r}-0.057^{* *} \\
(0.015)\end{array}$ & $\begin{array}{r}-0.152^{* * *} \\
(0.021)\end{array}$ & $\begin{array}{r}-0.107^{* * *} \\
(0.011)\end{array}$ & $\begin{array}{c}-0.116^{* *} \\
(0.027)\end{array}$ \\
\hline liquidity & $\begin{array}{r}-0.001^{* *} \\
(0.000)\end{array}$ & $\begin{array}{r}-0.003^{* * *} \\
(0.001)\end{array}$ & $\begin{array}{r}-0.002^{* * *} \\
(0.001)\end{array}$ & $\begin{array}{c}-0.002^{* *} \\
(0.001)\end{array}$ \\
\hline gov_effectiveness & $\begin{array}{r}-0.266^{* *} \\
(0.115)\end{array}$ & $\begin{array}{r}0.098 \\
(0.126)\end{array}$ & $\begin{array}{r}-0.525^{* *} \\
(0.003)\end{array}$ & $\begin{array}{c}-0.299^{* *} \\
(0.219)\end{array}$ \\
\hline Constant & $\begin{array}{r}-0.207^{* *} \\
(0.049)\end{array}$ & & & \\
\hline Observations & 1,431 & 1,340 & 1,340 & 1,340 \\
\hline R squared & 0.72 & & & \\
\hline Number of pairs & 91 & 91 & 91 & 91 \\
\hline GMM weights & & AB-n-step & AB-n-step & AB-n-step \\
\hline Coef. covar. method & & White diagonal & White diagonal & White diagonal \\
\hline Instrument rank & & 49 & 92 & 196 \\
\hline J-statistics & & 76.9 & 81.3 & 2009.8 \\
\hline Sargan test ( $\mathrm{p}$-value) & & 0.00 & 0.66 & 0.00 \\
\hline $\begin{array}{l}* * * p<0.01,{ }^{* *} p<0.05, * \\
\text { White period-Arellan } \\
\text { (2) model-The lagged } \\
\text { (3) model-The lagged } \\
\text { while others are treat } \\
\text { (4) model-All regress } \\
+ \text { Lagged variables for }\end{array}$ & $\begin{array}{l}\mathrm{p}<0.10 \\
\text {-Bond 2-st } \\
\text { dependent } \\
\text { dependent } \\
\mathrm{d} \text { as exoge } \\
\text { rs are treat } \\
\text { the instrur }\end{array}$ & $\begin{array}{l}\text { p estimator (itera } \\
\text { variable is treated } \\
\text { variable, debt_rati } \\
\text { eous } \\
\text { d endogenous } \\
\text { ental space are co }\end{array}$ & $\begin{array}{l}\text { to converge) for } \\
\text { redetermined wl } \\
\text { as well as gdp_g } \\
\text { aposed up to four }\end{array}$ & $\begin{array}{l}\text { ressors are assumed exogeneous } \\
\text { d as endogenous }\end{array}$ \\
\hline
\end{tabular}


Table 7: Dynamic approach with FGLS and GMM for subsample countries excluding PIIGS

\begin{tabular}{|c|c|c|c|}
\hline & $\begin{array}{l}\text { FGLS } \\
(1)\end{array}$ & $\begin{array}{l}\text { GMM } \\
\text { (2) }\end{array}$ & $\begin{array}{c}\text { GMM } \\
\text { (3) }\end{array}$ \\
\hline lagged_adjspread & $\begin{array}{l}0.524^{* *} \\
(0.149)\end{array}$ & $\begin{array}{l}0.353^{*} \\
(0.084)\end{array}$ & $\begin{array}{c}0.353^{* * *} \\
(0.000)\end{array}$ \\
\hline debt_ratio & $\begin{array}{c}0.002 \\
(0.002)\end{array}$ & $\begin{array}{c}0.003 \\
(0.019)\end{array}$ & $\begin{array}{c}0.003^{* * *} \\
(0.000)\end{array}$ \\
\hline GDP_growth & $\begin{array}{c}-0.017^{* * * *} \\
(0.007)\end{array}$ & $\begin{array}{l}-0.027 \\
(0.163)\end{array}$ & $\begin{array}{c}-0.027^{* * *} \\
(0.001)\end{array}$ \\
\hline liquidity & $\begin{array}{l}-0.001 \\
(0.000)\end{array}$ & $\begin{array}{l}-0.000 \\
(0.002)\end{array}$ & $\begin{array}{c}-0.000 * * * \\
(0.000)\end{array}$ \\
\hline gov_effectiveness & $\begin{array}{l}-0.144^{* *} \\
(0.048)\end{array}$ & $\begin{array}{l}-0.215 \\
(1.098)\end{array}$ & $\begin{array}{c}-0.215^{* * *} \\
(0.006)\end{array}$ \\
\hline Constant & $\begin{array}{c}0.026 \\
(0.028)\end{array}$ & & \\
\hline Observations & 576 & 540 & 540 \\
\hline R squared & 0.53 & & \\
\hline Number of pairs & 36 & 36 & 36 \\
\hline Cross section FE & YES & & \\
\hline Time FE & NO & & \\
\hline GLS weights & CSW & & \\
\hline GMM weights & & AB-n-step & AB-n-step \\
\hline Coef. covar. method & & White diagonal & White period \\
\hline Instrument rank & & 38 & 38 \\
\hline J-statistics & & 11 & 11 \\
\hline Sargan test (p-value) & & 0.99 & 0.99 \\
\hline
\end{tabular}

CSW-Cross section weights and ${ }^{* * *} \mathrm{p}<0.01,{ }^{* *} \mathrm{p}<0.05,{ }^{*} \mathrm{p}<0.10$

White period-Arellano-Bond 2-step estimator (iterate to converge) for GMM weights

(2)- (3)-(5)-(6) All regressors are treated endogenous and instrumental space is composed up to four lags 
Table 8: Description of variables

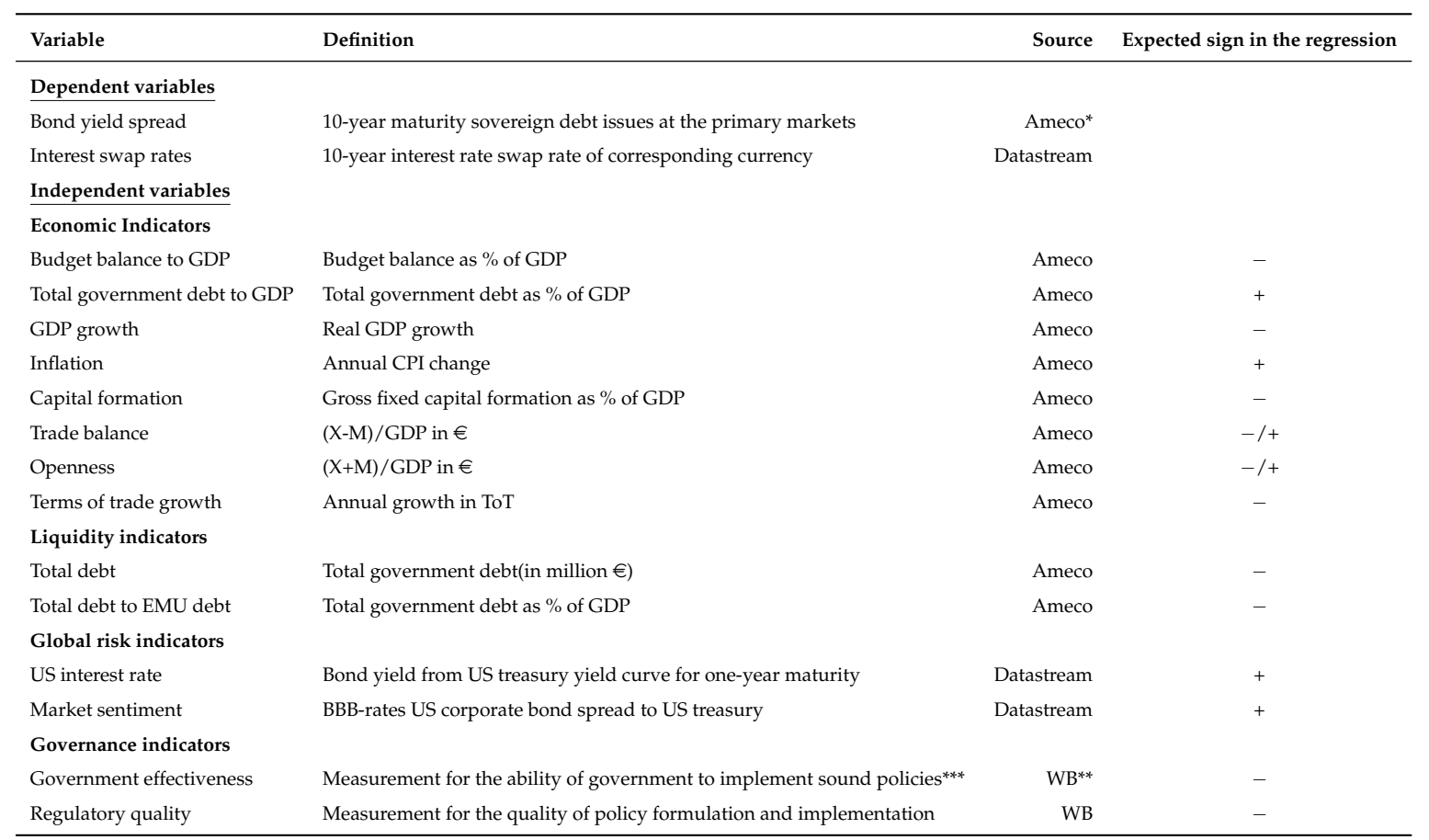

*Annual Macroeconomic Database of the European Commission** The World Bank

***Estimate of governance ranges from approximately -2.5 (weak) to 2.5 (strong) governance performance 
Table 9: Descriptive statistics

\begin{tabular}{|c|c|c|c|c|c|c|}
\hline Variable & Unit & Obs & Mean & Std. Dev. & Min & Max \\
\hline Adjusted spreads & $\%$ & 1456 & -0.05 & 1.64 & -13.14 & 13.06 \\
\hline Yield spreads & $\%$ & 1456 & -0.16 & 1.80 & -13.14 & 13.14 \\
\hline \multicolumn{7}{|l|}{ Economic Indicators } \\
\hline Budget ratio & $\%$ & 1456 & 0.65 & 4.84 & -31.11 & 28.46 \\
\hline Primary budget ratio & $\%$ & 1456 & 0.96 & 4.41 & -29.10 & 27.58 \\
\hline Primary bud. expenditure ratio & $\%$ & 1456 & 2.67 & 7.77 & -23.65 & 22.10 \\
\hline Primary bud. expenditure ratio (log) & & 1456 & 0.06 & 0.18 & -0.57 & 0.54 \\
\hline Government debt ratio & $\%$ & 1456 & 5.71 & 35.47 & -118.83 & 126.96 \\
\hline Government debt ratio (log) & & 1456 & 0.09 & 0.51 & -1.46 & 1.47 \\
\hline GDP growth rate & $\%$ & 1456 & -0.19 & 2.51 & -10.84 & 10.11 \\
\hline Annual CPI change & $\%$ & 1456 & -0.11 & 1.54 & -7.61 & 7.72 \\
\hline Gross fixed investment ratio & $\%$ & 1456 & 0.34 & 4.37 & -12.81 & 13.51 \\
\hline Gross fixed investment ratio (log) & & 1456 & 0.02 & 0.21 & -0.75 & 0.83 \\
\hline Trade balance ratio & & 1456 & 6.83 & 28.70 & -81.10 & 76.35 \\
\hline Openness & $\%$ & 1456 & 12.19 & 51.15 & -134.34 & 130.84 \\
\hline Openness (log) & & 1456 & 0.14 & 0.54 & -1.26 & 1.25 \\
\hline Annual terms of trade change & $\%$ & 1456 & -0.15 & 1.84 & -6.33 & 7.18 \\
\hline \multicolumn{7}{|l|}{ Liquidity indicators } \\
\hline Liquidity indicator & million $€$ & 1456 & -65.52 & 748.00 & -1995.50 & 1938.00 \\
\hline Liquidity indicator (log) & & 1456 & -0.23 & 1.60 & -3.58 & 3.58 \\
\hline Liquidty indicator 2 & $\%$ & 1456 & -0.01 & 0.11 & -0.23 & 0.23 \\
\hline \multicolumn{7}{|l|}{ Global risk indicators } \\
\hline US short interest rate & $\%$ & 1456 & 3.47 & 2.12 & 0.34 & 6.53 \\
\hline Market sentiments & $\%$ & 1456 & 2.55 & 0.95 & 1.62 & 5.64 \\
\hline \multicolumn{7}{|l|}{ Governance indicators } \\
\hline Government effectiveness & Index $* *$ & 1456 & 0.14 & 0.69 & -1.68 & 2.04 \\
\hline Regulatory quality & Index & 1456 & 0.01 & 0.51 & -1.39 & 1.25 \\
\hline
\end{tabular}

*Note that each variable indicates pairwise difference among the sample countries

**Estimate of governance ranges from approximately -2.5 (weak) to 2.5 (strong) governance performance 


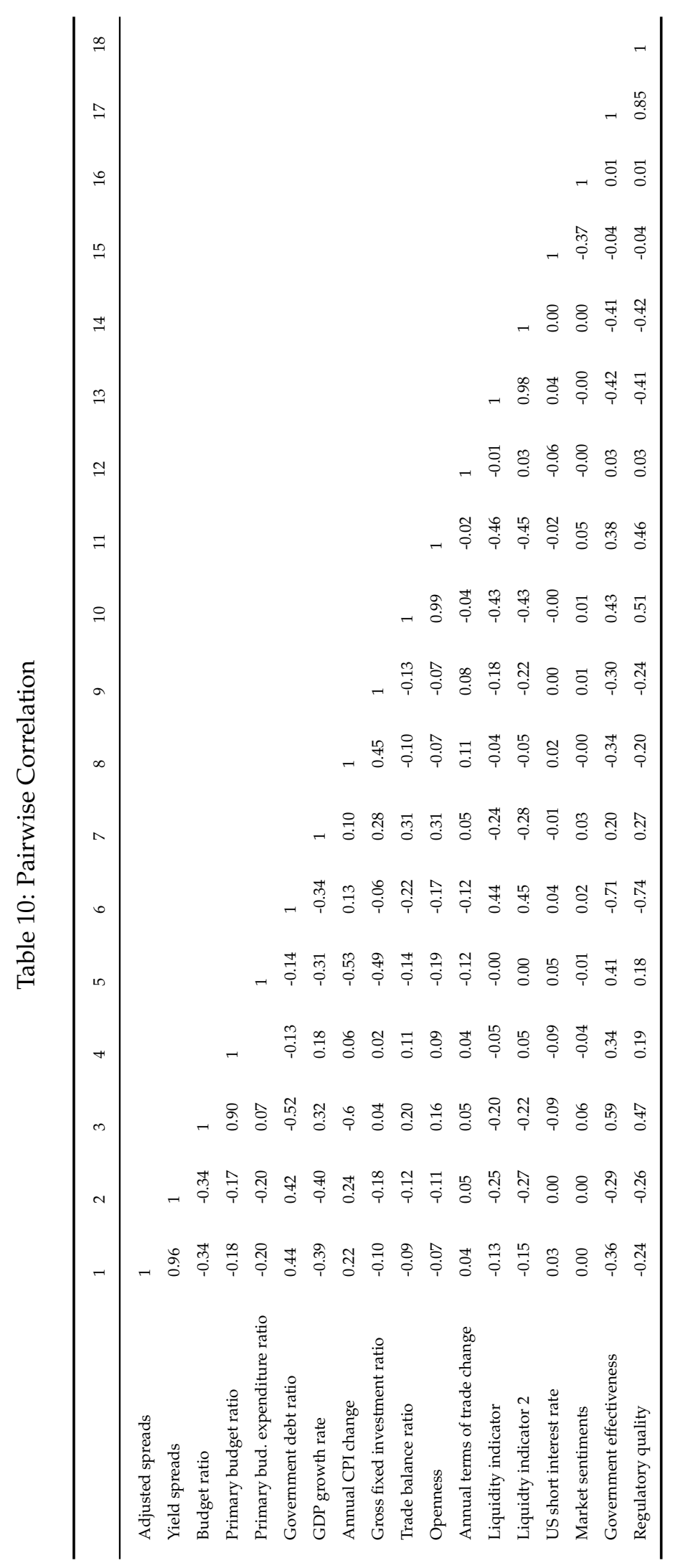

